\title{
STRATEGI PENINGKATAN KOMPETENSI PENGARAH ACARA TVRI JAWA BARAT SESUAI SKKNI
}

\author{
Yuni Wulandari \\ Program Studi Manajemen Produksi Siaran, Jurusan Penyiaran \\ Sekolah Tinggi Multi Media \\ Jalan Magelang Km. 6 Yogyakarta 55284 \\ No.Hp.: 081294552027,E-mail: mujonowulandari@yahoo.com \\ Ade Wahyudin \\ Program Studi Manajemen Teknik Studio Produksi, Jurusan Penyiaran \\ Sekolah Tinggi Multi Media \\ Jalan Magelang Km. 6 Yogyakarta 55284 \\ No.Hp.: 081321702620,E-mail:wahyudinade@gmail.com
}

\begin{abstract}
ABSTRAK
Sebuah produksi program acara televisi merupakan hasil proses kreatif yang rumit dan memerlukan kerja sama tim yang baik. Untuk itu, diperlukan seorang pengarah acara yang memiliki kompentensi dalam hal kemampuan skill penyiaran dan kepemimpinan dalam mengatur jalannya sebuah program acara televisi. Pengembangan SDM yang efektif juga dibutuhkan untuk meningkatkan kompetensi dan profesionalisme pengarah acara televisi. Berdasarkan wawancara dan observasi di Stasiun TVRI Jawa Barat didapatkan suatu fakta bahwa tidak ada seorang pun pengarah acara televisi yang memiliki sertifikasi profesi SKKNI pengarah televisi, walaupun secara pengetahuan dan kemampuan sudah mumpuni. Hal ini dikarenakan kurangnya dorongan dari pemangku kebijakan di Stasiun TVRI untuk meningkatkan kompetensi SDM melalui sertifikasi profesi. Dengan sertifikasi SKKNI, seorang pengarah acara dapat menunjukkan kompetensi yang berkaitan dengan profesi dan berlaku seumur hidup. Hasil analisis menggunakan pendekatan SWOT menghasilkan kesimpulan bahwa perlu adanya sosialisasi yang mendalam mengenai pentingnya sertifikasi profesi SKKNI di Stasiun TVRI Jawa Barat yang mendorong pengembangan kompetensi pengarah acara televisi. Hal ini perlu dukungan dari pihak stasiun televisi. Selain itu, perlu ditingkatkan kerja sama Lembaga Sertifikasi Profesi dengan industri televisi dan multimedia sehingga seorang pengarah acara televisi mampu menghasilkan karya program acara televisi yang baik dan berkualitas.
\end{abstract}

Kata kunci: kompetensi, pengarah acara televisi, SKKNI

\section{ABSTRACT}

Strategy for Improving the Competency of Program Directors of TVRI in West Java Complying with SKKNI. A television program production is a complex creative process and it requires a good teamwork. Therefore, it needs a competent program director having the skill in broadcasting and leadership in directing a television program. An effective development of human resources is also needed to enhance the competency and professionalism of a television program director. Based on an interview and an observation at TVRI station in West Java, a fact was found that none of the television program directors has a SKKNI certificate, even though they have mastered the skill and have been knowledgeable. This is due to the lack of encouragement from the policy makers at TVRI station to improve the human resource's competency with a professional certificate. With a SKKNI certification, a television program director can show his competence related to the profession and is valid for a lifetime. Therefore, using the SWOT approach, it can be concluded that there is a need for a socialization regarding the importance of the SKKNI professional certification for TVRI Station in West Java that will promote the development of the competency for television program directors. It will surely need a great support from the television station itself. In addition, a cooperation of the Professional Certification Institution with the television 
and multimedia industries is highly needed, so that the television program directors are able to produce high quality television programs.

Keywords: SKKNI, television director, competence

\section{PENDAHULUAN}

Produksi televisi adalah proses kreatif yang kompleks, dengan orang dan peralatan berinteraksi sedemikian rupa untuk menghasilkan suatu penciptaan karya siaran televisi. Dalam penciptaan tersebut, produksi televisi memerlukan sumber daya manusia yang kreatif untuk mengekspresikan suatu gagasan atau pesan dengan cara kerja sama tim kerabat kerja dan pengoperasian peralatan yang rumit untuk menghasilkan acara yang memenuhi tuntutan khalayak. Kemampuan dalam menerjemahkan visi merupakan kunci keberhasilan pembuatan program televisi. Kemampuan yang dimaksud adalah kemampuan masing-masing kerabat kerja dan divisi dalam menerjemahkan visi produksi itu sendiri. Sehebat apa pun visi yang diajukan sutradara dalam sebuah produksi, hasil akhirnya adalah sebuah gabungan kreatif banyak pihak. Pada prinsipnya, setiap kreativitas diakomodasi dalam sebuah "proses kreatif” yang dieksekusi oleh pengarah acara melalui “ACTION” sebagai kata kunci (Eaton, 2010 \& Purwanto, 2019).

Pengarah acara merupakan penentu arah dari suatu produksi program acara televisi. Oleh karena itu, seorang pengarah acara haruslah memiliki kompetensi atau kriteria yang layak (Luthfi, 2018).

Beberapa kompetensi atau kriteria yang diperlukan oleh pengarah acara itu menurut Naratama (2013) antara lain: (1) memiliki pengetahuan yang cukup tentang perencanaan dan produksi acara televisi, (2) memiliki wawasan yang luas (sehingga memiliki kemampuan konseptual), (3) mampu menerjemahkan naskah ke dalam bentuk visual, (4) memahami filosofi gambar/visual, memahami grammar of edit, (6) berjiwa seni (pekerja televisi adalah perpaduan antara pekerja teknis dan artistik), (7) mampu berkomunikasi dengan kelompok produksi (tentunya sesuai kaidah-kaidah pertelevisian), dan (8) memiliki jiwa kepemimpinan dan komitmen.

$$
\text { Untuk dapat meningkatkan }
$$
profesionalisme, kemampuan, dan kompetensi, seorang pengarah acara perlu mendapatkan pelatihan dan sertifikasi sesuai dengan profesinya. Hal ini tertuang dalam Standar Kompetensi Kerja Nasional Indonesia (SKKNI) pengarah acara, yang ditetapkan oleh Badan Nasional Sertifikasi Profesi (BNSP). Sebagaimana tertuang dalam Keputusan Menteri Ketenagakerjaan Republik Indonesia Nomor 346 Tahun 2015 Tentang Penetapan Standar Kompetensi Kerja Nasional Indonesia Kategori Informasi dan Komunikasi Golongan Pokok Produksi Gambar Bergerak, Video dan Program Televisi, Perekaman Suara dan Penerbitan Musik Bidang Penyutradaraan Televisi.

Kompetensi seorang pengarah acara diukur dengan SKKNI. Namun, berdasarkan publikasi penelitian berjudul "Profesionalisme Pengarah Acara dalam Produksi Program Campursari di TVRI Jawa Timur Sesuai Arahan SKKNI" didapatkan simpulan bahwa pengarah acara di TVRI Jawa Timur belum ada satu pun yang mengikuti sertifikasi profesi oleh Lembaga Profesi BNSP. Walaupun dalam melaksanakan tugas dan tanggung jawab sebagai pengarah acara sudah kompeten, hal ini terlihat dalam strategi produksi program Campursari Tambane Ati yang dibagi menjadi tiga tahapan. Tahap praproduksi meliputi penentuan tema yang berkaitan dengan 
kehidupan masyarakat sehari-hari, melakukan audisi secara langsung, penataan artistik, strategi memunculkan gimmick, dan pemilihan shot, serta mengundang penonton datang ke studio.

Tahap produksi adalah pergerakan kamera yang dinamis dan keterlibatan penonton di studio sebagai bagian dalam proses produksi. Tahap pascaproduksi adalah dengan penyuntingan secara linier; pergantian gambar dengan menggunakan teknik cut to cut, dissolve, dan fade secara langsung melalui switcher. Beberapa strategi tersebut dilakukan pengarah acara Campursari Tambane Ati agar program menjadi tayangan yang baik. Walaupun demikian, arahan SKKNI sesuai kebijakannya tidak sepenuhnya dilakukan oleh pengarah acara tersebut (Wulandari, 2017; Wulandari, 2018).

Kajian ini terinspirasi dari cara kerja pengarah acara dan strategi untuk menuju profesionalisme serta kompetensi pengarah acara. Penelitian ini bertujuan untuk mengetahui kompetensi pengarah acara sesuai dengan arahan SKKNI. Selain itu, juga menganalisis kompetensi pengarah acara televisi stasiun TVRI Jawa Barat, serta strategi meningkatkan kompetensi sesuai SKKNI sehingga menjadi masukan bagi pengembangan SDM di Stasiun TVRI Jawa Barat.

Untuk menganalisis diperlukan beberapa pemahaman terkait istilah serta teori yang terkait dengan kajian ini. Istilah pertama adalah pengarah acara, yaitu seseorang yang ditunjuk untuk bertanggung jawab secara teknis pelaksanaan produksi satu mata acara siaran. Pengarah acara memiliki peran yang sangat strategis dalam sebuah produksi televisi karena bertugas mengendalikan kegiatan produksi di lapangan (Fachruddin, 2014 \& Kustanto, 2016).

Pengertian lain sutradara/pengarah acara harus dipahami agar bekerja sesuai dengan tugasnya, antara lain:

Sutradara televisi adalah seseorang yang mampu mengarahkan dan menciptakan sebuah karya seni audiovisual dalam bentuk format acara televisi drama atau nondrama dengan menggunakan sistem rekaman gambar elektronik, baik untuk single camera maupun multi camera (Naratama, 2013).

Darwanto Sastro Subroto mengartikan seorang sutradara sebagai:

orang yang bertugas seorang produser, menjadi suatu bentuk dan susunan gambar dan suara, dalam menginterpretasikan harus selalu mengingat akan kepentingan penontonnya. Agar hasil karyanya menjadi tontonan yang benar-benar dapat dinikmati, diminati, dan menjadi tuntunan baginya (Subroto, 1994).

Menurut Naratama (2013), terdapat tiga karakteristik sutradara/pengarah antara lain: (1) pengarah acara sebagai pemimpin. Jiwa kepemimpinan merupakan aspek utama seorang pengarah acara. Tanpa kepemimpinan atau leadership, sutradara/pengarah acara tidak pernah bisa menciptakan karya seni sesuai dengan yang diinginkan. Dalam memimpin sebuah tim produksi yang terdiri dari berbagai macam latar belakang, terkadang sutradara atau pengarah acara harus bersikap rendah hati dan menghargai orang-orang yang telah bekerja sama dalam proses produksi; (2) pengarah acara sebagai seniman. Sebagai kreator yang bertanggung jawab terhadap karya akhir tayangan audiovisual, seorang pengarah acara dituntut untuk menjadi seorang seniman yang mempunyai cita rasa tinggi tentang nilai kesenian dan kebudayaan. Di sinilah seorang sutradara perlu mempunyai pemahaman atas nilai keindahan terhadap seni yang merupakan kebutuhan utama, selain wawasan dan pengetahuan secara umum. Kecintaan akan suatu budaya adalah faktor yang akan menyentuh setiap sendi-sendi imajinasi 
seni visual baik dalam bentuk dramatik maupun nondramatik. Selanjutnya, karya seni itu sendiri akan memuaskan dahaga para penikmat kesenian atau penonton; dan (3) pengarah acara sebagai penasihat teknik. Seorang pengarah acara atau pengarah acara harus siap menjalankan tugas sebagai penasihat teknik produksi, baik untuk produksi single maupun multicamera. Kemampuan teknik ini harus didukung dengan pengetahuan dan wawasan broadacast yang memadai, dari unsur video, audio, tata cahaya, hingga ke peralatan editing untuk pascaproduksi. Technical director adalah partner terbaik bagi pengarah acara untuk menciptakan program siaran yang sesuai dengan pangsa penonton (Morissan, 2008).

Pemahaman lain yang diperlukan adalah tentang element of the shot. Sutradara harus memahami apa saja dan apa yang dimaksud dengan element of the shot sesuai dengan judul yang diangkat. Element of the shot terdiri dari motivasi, informasi, komposisi, camera angle, suara, dan continuity. Dari enam elemen, hanya tiga element of the shot yang merupakan landasan utama karena tiga hal ini menjadi dasar yang secara langsung akan berkaitan dengan tiga hal lainnya. Berikut tiga element of shot yang menjadi landasan sutradara menurut Thompson (2009).

Pertama, information (informasi). Sebuah shot harus menggambarkan informasi yang ingin disampaikan kepada pemirsa. Misalnya, sebuah adegan seorang musisi sedang menampilkan solo gitar dalam sebuah konser musik. Maka, informasi gambar yang disajikan adalah panggung konser, posisi pemain gitar, wajah pemain gitar, petikan gitar, dan sambutan penonton. Hasil shot tersebut yang nantinya mempunyai informasi lengkap yang sangat didambakan pemirsa. Dengan ini kreativitas dibutuhkan untuk menciptakan angle-angle camera yang dapat memperindah tayangan.

\section{Kedua, composition (komposisi).} Pengambilan gambar harus memerhatikan komposisi gambarsupaya gambar dapatberbicara dengan sendirinya. Ada empat bagian yang perlu diperhatikan, yaitu framing (pembingkaian gambar), ilusion of depth (kedalaman dalam dimensi gambar), subject or object (subjek atau objek gambar), dan colour (warna). Keempat bagian ini akan menyatu dalam komposisi shot yang akan dibuat.

Ketiga, sound (suara). Suara juga sangat memengaruhi makna sebuah gambar. Misalnya, sebuah shot jalan raya. Mungkin kameraman tidak dapat memberikan gambar jalan raya yang padat, macet, polusi bising, dan sebagainya. Namun, dapat dipertegas suasana dengan memberikan suara klakson mobil, sempritan polisi, derungan mesin mobil bus hingga ke teriakan kondektur bus mencari penumpang. Shot sangat dipengaruhi dan memengaruhi kebutuhan suara, baik dalam bentuk sound effect, live sound record, hingga ke pembuatan musik ilustrasi pendukung suasana.

Selain itu, perlu dipahami juga tentang Standar Kompetensi Kerja Nasional Indonesia (SKKNI) untuk sutradara/pengarah acara televisi, yang merupakan acuan dalam mengukur kualitas sumber daya manusia sebagai sutradara/ pengarah acara televisi. Di dalamnya termuat kompetensi profesional yang dituntut dari seorang produser televisi. Tingkat kompetensi tersebut harus dibuktikan dengan sertifikasi yang didapat melalui uji kompetensi yang dilaksanakan oleh Lembaga Sertifikasi Profesi Penyiaran.

Dengan disusun dan diberlakukannya Standar Kompetensi Kerja Nasional Indonesia Produksi Program Televisi, dunia pendidikan 
dan dunia industri pertelevisian nasional serta masyarakat yang berkepentingan dapat menggunakannya sebagai acuan dalam mengembangkan standardisasi kualitas pendidikan dan untuk mendapatkan pengakuan profesi/kompetensi kerja baik secara nasional maupun internasional.

Tabel 1 Daftar Unit Kompetensi (Indonesia, 2015)

\begin{tabular}{|c|c|}
\hline No. & Judul Unit Kompetensi \\
\hline 1 & $\begin{array}{l}\text { Menerjemahkan Desain Program Acara } \\
\text { Televisi yang Ditetapkan Produser }\end{array}$ \\
\hline 2 & $\begin{array}{l}\text { Menghubungkan Pesan Program Acara dan } \\
\text { Nilai Jual }\end{array}$ \\
\hline 3 & $\begin{array}{l}\text { Menerapkan Standar Moral, Etika, dan } \\
\text { Nilai-Nilai Luhur Bangsa }\end{array}$ \\
\hline 4 & $\begin{array}{l}\text { Menerapkan Hukum dan Peraturan- } \\
\text { Peraturan yang Berlaku }\end{array}$ \\
\hline 5 & $\begin{array}{l}\text { Merencanakan Produksi Acara Televisi } \\
\text { Sesuai Format Teknis yang Ditetapkan } \\
\text { Produser }\end{array}$ \\
\hline
\end{tabular}

Merencanakan Produksi Berdasarkan

6 Kategori/Jenis Acara yang Ditetapkan Produser

7 Merencanakan Produksi Berdasarkan Lokasi Acara

8 Menerjemahkan Rundown dan Skenario ke Dalam Konsep Penyutradaraan

9 Menetapkan Unsur-Unsur Elemen Artistik Produksi Acara Televisi

10 Menetapkan Pengisi Acara

11 Melaksanakan Rapat-Rapat Praproduksi dan Produksi

Mengarahkan Pengambilan Gambar

12 dan Suara Sesuai dengan Konsep Penyutradaraan yang ditetapkan

13 Mengarahkan pengambilan Gambar Sesuai dengan Format Teknis Audiovisual

\begin{tabular}{|c|c|}
\hline No. & Judul Unit Kompetensi \\
\hline 14 & $\begin{array}{l}\text { Menyelaraskan Materi Audiovisual Sesua } \\
\text { dengan Konsep Acara }\end{array}$ \\
\hline 15 & $\begin{array}{l}\text { Membuat Review Hasil Akhir Produksi } \\
\text { Acara Televisi }\end{array}$ \\
\hline 16 & Memperhitungkan Anggaran Produksi \\
\hline 17 & $\begin{array}{l}\text { Menangani Sumber Daya Manusia dalam } \\
\text { Produksi Acara Televisi }\end{array}$ \\
\hline 18 & $\begin{array}{l}\text { Menangani Sarana Prasarana Produksi } \\
\text { Acara Televisi }\end{array}$ \\
\hline 19 & $\begin{array}{l}\text { Membandingkan Data Riset Kepemirsaan } \\
\text { dan Program Pesaing untuk Evaluasi } \\
\text { Program Televisi }\end{array}$ \\
\hline 20 & $\begin{array}{l}\text { Mengerjakan Materi Promosi Program } \\
\text { Acara Televisi }\end{array}$ \\
\hline
\end{tabular}

Kajian ini menggunakan metode penelitian kualitatif, dengan pendekatan studi kasus yang dilakukan di Stasiun TVRI Jawa Barat. Data penelitian didapatkan dengan melakukan beberapa pendekatan antara lain: (1) teknik dokumentasi, yaitu mengumpulkan dan menganalisis setiap kegiatan yang membutuhkan seorang pengarah acara/sutradara, antara lain foto-foto kegiatan acara dan rekaman program acara hiburan; (2) teknik observasi, berupa pengamatan terhadap proses kegiatan yang berhubungan dengan pengarah acara/sutradara saat melakukan kegiatan sesuai tugas dan tanggung jawabnya; (3) teknik wawancara dengan Produser Acara Musik Legend, Penta Aji Arief, S.T., M.Si., Kepala Bidang Siaran/ Program, M. Sanif, S.E., M.M., serta Pengarah Acara Musik Legend, Dina Gitawati.

Lokasi penelitian sesuai dengan proses observasi dan pengumpulan data dari wawancara narasumber, penelitian dilaksanakan di Televisi Republik Indonesia (TVRI) Jawa Barat pada 18 Juli 2019 s.d. 22 Juli 2019. Selain mendapatkan 
data primer, penelitian ini juga mengkaji berbagai literatur dan pendapat para ahli mengenai kompetensi pengarah acara televisi yang didapatkan dari berbagai media. Literatur dalam hal ini berupa buku, hasil penelitian, catatan, serta sumber-sumber lain dari internet.

Studi kasus menghasilkan data untuk selanjutnya dianalisis untuk menghasilkan teori berdasarkan data kualitatif yang diuraikan secara deskriptif untuk melengkapi dan mempertajam analisis pembahasan. Pendekatan StrenghtWeaknees-Opportunity-Threat

(SWOT) digunakan untuk menghasilkan rekomendasi penyelesaian masalah dengan melihat kondisi internal dan eksternal. Dengan demikian, menghasilkan solusi dan masukan yang komprehensif.

\section{PEMBAHASAN}

\section{Analisis Internal}

Penelitian ini menemukan permasalahan yang sama dengan TVRI Jawa Timur dan Jawa Tengah. Dari tujuh orang pengarah acara yang ada di TVRI Jawa Barat belum satu pun mengikuti sertifikasi untuk mengukur standar kompetensi yang diselenggarakan lembaga sertifikasi profesi BNSP tentang kompetensi pengarah acara sesuai dengan arahan SKKNI.

Pengarah acara di Stasiun TVRI Jawa Barat sudah menggunakan teori sutradara, pemilihan type shot, serta element of the shot, teknik tata cahaya, dalam produksi (rekaman) Musik Legend. Dengan demikian, menghasilkan karya produksi yang baik karena pengarah acara juga menggabungkan motivasi, pengetahuan, dan keahliannya.

Dalam pengerjaan program Music Legend, pengarah acara melaksanakan tahapan praproduksi acara televisi yang merupakan fungsi utama seorang sutradara atau pengarah acara.
Selain mengatur produksi acara televisi, ia juga mengombinasikan unsur-unsur pascaproduksi acara televisi, mempersiapkan sumber daya produksi acara televisi, serta menciptakan materi promosi program acara televisi. Dalam produksi pengarah acara Musik Legend, pengarah acara melaksanakan tahapan-tahapan produksi.

Di dalam proses produksi acara televisi terdapat kompleksitas yang cukup tinggi baik dari perangkat keras maupun perangkat lunaknya, maka perlu digunakan suatu metode/cara/teknik yang disebut Standard Operation Procedure (SOP). Produksi suatu acara televisi mungkin sebenarnya hanya memerlukan waktu paling lama 30 menit, tetapi ini hanyalah sebagaian kecil dari keseluruhan proses produksi. Jauh sebelum memasuki studio atau ruang kontrol produksi, program harus direncanakan dengan baik dan hati-hati serta perlu persiapan yang rinci dan lengkap.

Hal ini merupakan kerja dari sejumlah langkah yang bisa dibagi menjadi empat tahap. Pertama, pre-production planning. Preproduction planning/perencanaan praproduksi bagi suatu acara mungkin dimulai sejak berharihari, berminggu-minggu, atau bahkan berbulanbulan sebelum tanggal produksi yang sebenarnya. Semakin rumit produksi tersebut, maka semakin banyak waktu yang diperlukan sebelum produksi. Selama tahap ini, produser dan pengarah acara bekerja sama dengan penulis naskah untuk menyelesaikan naskah dan mengembangkan seluruh pendekatan produksi. Anggota tim kunci produksi acara televisi, antara lain; produser, pengarah acara penulis naskah, pengarah teknik, teknisi audio, penata cahaya, dan perancang dekor- mereka bertemu untuk membahas acara yang akan dibuat dan masing-masing bagian yang dilakukan. Hal itu menjadi inti bagi suksesnya suatu paket produksi acara televisi. 
Banyak kesulitan bisa dihindari jika produksi telah direncanakan dengan hati-hati sebelumnya, dengan seluruh anggota kunci dari tim produksi itu menyadari sepenuhnya sumbang saran serta ruang lingkup tugas tanggung jawab mereka. Jauh lebih mudah mengoreksi masalah di atas kertas selama tahap praproduksi dibandingkan nanti pada saat kesulitan yang tidak diantisipasi dapat menghentikan kegiatan produksi, mengukur waktu produksi dan meningkatkan biaya produksi.

Kedua, set up and rehearsal. Set Up (penataan) merupakan upaya untuk menyiapkan studio dan ruang kontrol produksi sebelum produksi yang sebenarnya dilakukan. Waktu yang diberikan untuk penataan akan ditentukan selama perencanaan praproduksi dan biasanya tergantung pada tingkat kerumitan program dan ukuran besarnya anggaran. Untuk memaksimalkan waktu yang tersedia, semua anggota kunci dari tim produksi harus benarbenar tahu apa yang dibutuhkan dan mengawasi kru mereka dalam menjalankan tugas tersebut. Para kru harus dapat bekerja bersamaan, karena tidaklah efisien jika harus menunggu hingga penataan yang lain selesai.

Ketiga, rehearsal. Rehearsal atau geladi bersih merupakan tahapan latihan. Selama latihan di dalam studio, segala unsur produksi seharusnya hadir bersama-sama seperti penataan kostum dan penataan pencahayaan, musik dan efek suara, pengambilan gambar, sisipan film atau rekaman suara dari tape, dan sebagainya. Pengarah acara bekerja menyempurnakan penampilan pengisi acara dan pengambilan gambar, sedangkan anggota tim produksi lainnya harus mengamati dan mengoreksi masalah apa saja yang muncul. Teknisi audio bisa memperbaiki posisi pelantang, pengarah pencahayaan mungkin menambahkan alat lainnya untuk menerangi area yang gelap, perekayasa dekor mungkin memutuskan untuk memindahkan beberapa properti yang menyulitkan kamera dalam mengambil gambar. Selama latihan produser dan pengarah acara dengan cermat mengamati monitor program, bertindak sebagai wakil pemirsa/penonton, dan membuat catatan tentang perubahan-perubahan yang disarankan untuk memperbaiki kualitas estetika dan teknis dari produksi tersebut. Selama waktu istirahat, catatan itu dibahas bersama pengarah acara, pengisi acara, dan kerabat kerja produksi.

Keempat, production. Tahapan ini merupakan upaya mengubah bentuk naskah atau run down acara menjadi bentuk audiovisual, ketika seluruh pendukung dan tim kerja produksi terlibat. Perlu diketahui bahwa pelaksanaan produksi tergantung dari tuntutan naskah. Dengan demikian, karakter produksi acara televisi pada umumnya lebih ditentukan oleh tuntutan karakter naskah atau karakteristik acaranya. Pengamatan serta pengumpulan data dilakukan melalui pengarah acara Musik Legend yang dapat menjelaskan secara detail tugas dan tanggung jawab seorang pengarah acara.

Menurut pengarah acara yang menjadi narasumber, kondisi TVRI Jawa Barat cukup kondusif. Tidak ada permasalahan terutama menyangkut biaya sehingga sebagai pengarah acara sepenuhnya melaksanakan tahapantahapan proses produksi.

Berdasarkan pengamatan serta melihat live recording hasil produksi pengarah acara di TVRI Jawa Barat dengan acara Musik Legend, pengarah acara sudah melakukan proses produksi sesuai arahan SKKNI, serta menggabungkan motivasi, pengetahuan, dan keahlian. Kompetensi sebagai pengarah acara dalam mengemas acara melalui type shoot serta dinamisasi gambar sangat profesional 
walaupun belum mengikuti uji kompetensi yang diselenggarakan lembaga sertifikasi profesi dalam hal ini BNSP.

Kompetensi pengarah acara sesuai dengan arahan SKKNI yang fungsi utamanya adalah pengarah acara dapat membuat atau melaksanakan praproduksi acara televisi, mengatur produksi acara televisi, mengombinasikan unsur-unsur pascaproduksi acara televisi, mempersiapkan sumber daya produksi acara televisi, serta menciptakan materi promosi program acara televisi. Data yang didapatkan di lapangan sebagian besar arahan SKKNI belum maksimal dalam pelaksanaannya. Standar Kompetensi Kerja Nasional Indonesia untuk Sutradara Televisi merupakan acuan dalam mengukur kualitas sumber daya manusia sebagai pengarah acara/sutradara televisi. Di dalamnya termuat kompetensi profesional yang dituntut dari seorang produser televisi. Tingkat kompetensi tersebut dibuktikan dengan sertifikasi yang didapat melalui uji kompetensi yang dilaksanakan oleh Lembaga Sertifikasi Profesi Penyiaran.

\section{Analisis Eksternal}

Faktor-faktor eksternal yang yang bersifat peluang dalam peningkatan kompetensi pengarah acara sesuai SKKNI adalah: (a) Kebijakan Peraturan Pemerintah Nomor 31 Tahun 2006 Tentang Sistem Pelatihan Kerja Nasional; (b) Kebijakan Keputusan Menteri Ketenagakerjaan Republik Indonesia Nomor 346 Tahun 2015 Tentang Penetapan Standar Kompetensi Kerja Nasional Indonesia Kategori Informasi dan Komunikasi Golongan Pokok Produksi Gambar Bergerak, Video dan Program Televisi, Perekaman Suara dan penerbitan Musik Bidang Penyutradaraan Televisi; (c) perubahan industri penyiaran yang semakin kompetitif menuntut kompetensi dan profesionalisme profesi pengarah acara televisi;(d) perkembangan konvergensi teknologi informasi dan komunikasi sangat mendukung profesionalisme profesi pengarah acara televisi, (e) sertifikasi keahlian sangat dihargai di dunia kerja dewasa ini dan pada masa yang akan datang; (f) belum adanya stasiun televisi yang mengirimkan pengarah acara televisi untuk mengikuti sertifikasi SKKNI.

Sementara itu, ancaman dari faktor eksternal antara lain: (a) perkembangan teknologi media digital streaming mengancam industri pertelevisian, (b) kurangnya sosialisasi mengenai sertifikasi SKKNI pengarah acara televisi, (c) kurangnya kesadaran pemangku kepentingan di industri televisi terhadap pentingnya sertifikasi SKKNI pengarah acara televisi.

\section{Analisis Strategi SWOT}

Strategi Strenght-Opportunity (SO): (1) meningkatkan sosialisasi terhadap sertifikasi SKKNI pengarah acara televisi; (2) melakukan sosialisasi tidak hanya kepada industri televisi, namun kepada alumni SMK atau mahasiswa jurusan multimedia yang berminat terhadap SKKNI pengarah acara televisi; (3) membangun jaringan antarstasiun TVRI untuk mempromosikan sertifikasi SKKNI pengarah acara televisi.

Strategi WO Weakness-Opportunity (WO): (1) mendorong pihak perusahaan televisi untuk mengikutsertakan pengarah acara televisi dalam sertifikasi SKKNI pengarah acara televisi dan (2) mendorong pengarah acara TVRI Jawa Barat untuk tetap melaksanakan pekerjaannya secara profesional sesuai arah kompetensi dari SKKNI.

\section{Strategi Strenght-Threat (ST):} mendorong pihak perusahaan televisi untuk mengikutsertakan pengarah acara televisi dalam 
sertifikasi SKKNI pengarah acara televisi dan (2) penyesuaian kurikulum SKKNI dengan perkembangan teknologi terutama digital streaming.

\section{Strategi Weakness-Threat (WT):} mendorong kerja sama LSP(Lembaga Sertifikasi Profesi) SKKNI pengarah acara televisi dengan industri televisi.

\section{SIMPULAN}

Berdasarkan analisis, dapat disimpulkan bahwa pengarah acara di Stasiun TVRI Jawa Barat telah memiliki kompetensi dan pengetahuan yang baik dalam melakukan pekerjaannya sebagai pengarah acara televisi, namun belum ada satu pun yang memiliki sertifikasi SKKNI pengarah acara televisi. Akan tetapi, dukungan dari pihak yang berwenang dalam pengembangan SDM di Stasiun TVRI Jawa Barat untuk mengirimkan pengarah acara televisi dalam sertifikasi SKKNI masih kurang.

Perlunya dukungan dari pihak terkait di Stasiun TVRI Jawa Barat untuk meningkatkan kompetensi sumber daya manusianya dengan mengikuti sertifikasi SKKNI pengarah acara televisi dan kerja sama Lembaga Sertifikasi Profesi (LSP) SKKNI pengarah acara televisi dengan industri televisi. Dengan sertifikasi, seorang pengarah acara dapat menunjukkan kompetensinya yang berkaitan dengan profesi karena sertifikasi profesi bisa dipakai seumur hidup.

\section{KEPUSTAKAAN}

Eaton, M. M. (2010). Persoalan-Persoalan Dasar Estetika. Jakarta: Saleba Humanika.

Fachruddin, A. (2014). Dasar-Dasar Produksi Televisi. Jakarta: Kencana.

Indonesia, K. K. R. Keputusan Menteri Ketenagakerjaan Republik Indonesia Nomor 346 Tahun 2015 Tentang Penetapan Standar Kompetensi Kerja Nasional Indonesia Kategori Informasi dan
Komunikasi Golongan Pokok Produksi Gambar Bergerak, Video dan Program Televisi, Perekaman Suara, Pub. L. No. 346 Tahun 2015, 84 (2015).

Kustanto, L. (2016). "Analisis Naratif: Kemiskinan dalam Program Reality Tv "Pemberian Misterius" di Stasiun SCTV". REKAM: Jurnal Fotografi, Televisi, dan Animasi, 11(2), 109. https://doi. org/10.24821/rekam.v11i2.1297

Luthfi, A. (2018). "Pendidikan Seni Film dan Televisi Menjadi Penggerak Industri Ekonomi Kreatif". REKAM: Jurnal Fotografi, Televisi, dan Animasi, 13(2), 99. https://doi.org/10.24821/rekam.v13i2.1933

Morissan. (2008). Jurnalistik Televisi Muthaktir. Bogor: Ghalia Indonesia.

Naratama. (2013). Menjadi Sutradara Televisi. Jakarta: Grasindo.

Purwanto, Puji Lestari, A. W. (2019). "Evaluasi Pelaksanaan Digitalisasi Penyiaran di LPP TVRI Stasiun Jakarta". Jurnal Heritage, $7(2)$.

Subroto, D. S. (1994). Produksi Acara Televisi. Yogyakarta: Duta Wacana University Press.

Thompson, Roy, C. B. (2009). Grammar of the Shot. Oxford: Elsevier.

Wulandari, Y. (2018). Kompetensi Pengarah Acara Televisi sesuai SKKNI (Studi Kasus di TVRI Jawa Tengah). Yogyakarta.

Wulandari, Y. (2017). Profesionalisme Pengarah Acara dalam Produksi Program Campursari di TVRI Jawa Timur (Studi Kasus di TVRI Jawa Timur). Yogyakarta. 